\title{
Editorial
}

This special survey of North Korea, like the one on North Vietnam in our ninth issue, is designed to provide information and analysis of a communist country about which comparatively little is known. It has been prepared with considerable help from Professor Robert A. Scalapino, to whom this journal is much indebted. 


\section{COMMUNIST EDUCATION}

\section{Edited by EDMUND J. KING}

Recent developments and present trends in Communist education are traced in this authoritative survey by specialists who have professionally studied and visited the U.S.S.R. and other Communist countries. Eight chapters deal with particular aspects: ideology, psychology, the selective process, the rôles of teachers and parents, polytechnical education, the universities and professional institutes. Three chapters survey East Germany, Poland and China as special case-studies. A concluding chapter examines common ground between Communist and other systems.

25s.

\section{CHINESE \\ THOUGHT}

\section{H. G. CREEL}

A readable account of the development of Chinese thought from Confucius to Mao Tse-tung.

' I can confidently recommend this book to anyone who wants to make a first acquaintance with systems of thought as important as those in our classical heritage.'-Maurice Collis, Time \& Tide

12s. 6d.

\section{METHUEN}

\section{PREUVES}

publie dans son numéro d'Avril

\section{KARL JASPERS}

L'expérience politique d'un philosophe (entretien avec François Bondy)

\section{RAYMOND ARON}

La théorie du développement et les problèmes idéologiques de notre temps

WLADIMIR WEIDLE

La parole de l'écrivain dans le monde d'aujourd'hui

\section{MAURICE GIRODIAS}

La mort de Roger Casement

JEAN ATLAN-AIME PATRI

Dialogue sur l'art non-figuratif

\section{JAMES BALDWIN}

Ce qui survivra de Richard Wright

PREUVES: 18, avenue de l'Opéra-PARIS (ler)

Le $\mathrm{N}^{\circ}$ de 96 pp. ill. France: $3,30 \mathrm{~F}$.

Etranger: $3,60 \mathrm{~F}$.

C.C.P. PARIS $178-00$

Un ancien numéro sera gracieusement envoyt sur simple demande, comme specimen 